\title{
Christian Weise and his Gedichte von der Sicilianischen Argenis (1683): The Practice of Politics
}

\author{
Anna Linton \\ King's College London \\ anna.linton@kcl.ac.uk
}

Recepción: 11/04/2016, Aceptación: 15/06/2016, Publicación: 23/11/2016

\begin{abstract}
In March 1683 the pedagogue, dramatist and novelist Christian Weise directed his German stage version of Barclay's Argenis, which was performed for parents and local dignitaries by the boys at his grammar school in the Saxon city of Zittau. The Gedicht von der Sicilianischen Argenis was, in fact, one of three plays performed on consecutive days during Shrovetide 1683, and one of well over fifty plays written by Weise for performance on the school stage. Weise adapted Argenis as a play in order to teach schoolboys important political lessons, to prepare them for their roles as future civil servants, and to provide them with essential training in practical modern rhetoric. This article discusses Weise's intentions in staging Argenis, and considers how he adapted the novel for the demands of a necessarily large cast (65 named parts). It sets it in the context of the 1683 trilogy, which included a biblical drama about Saul's persecution of David and a comedy entitled Die Verkehrte Welt (The Topsy-Turvy World), and it analyses the play against the background of his dramaturgical, pedagogical and political writings.
\end{abstract}

Keywords

Christian Weise; John Barclay; school drama; pedagogy; oratory; civic ethics

\section{Resumen}

Christian Weise y su Gedichte von der Sicilianischen Argenis (1683): La politica en práctica

En marzo 1683, el dramaturgo, pedagogo y novelista alemán Christian Weise, llevó al escenario su versión teatral de Argenis de Barclay, representada ante un público de padres y dignitarios por los estudiantes de su instituto en la ciudad de Zittau (Sajonia). 
De hecho, Gedicht von der Sicilianischen Argenis formó parte de una trilogía de dramas representados consecutivamente durante Carnestolendas y constituye uno de más de cincuenta comedias escritas por Weise para el escenario escolástico. Weise adaptó Argenis para dar a sus alumnos una lección práctica de política y oratoria con el fin de prepararles para cargos cívicos. Este artículo reseña tanto las intenciones de Weise como los obstáculos que tuvo que superar para satisfacer las exigencias de un reparto extensivo de 65 papeles. Se explica la función de la obra en la trilogía de 1683, que también incluía un drama bíblico sobre la persecución de David por parte de Saul y una comedia intitulada Die Verkehrte Welt (El mundo al revés). Finalmente se sitúa la obra en el contexto más amplio de sus otros escritos dramáticos, pedagógicos y políticos.

Palabras clave

Christian Weise; John Barclay; drama escolástico; pedagogía; oratoria; ética cívica

A cursory glance at the Argenis dramas of Du Ryer, Calderón and Christian Weise highlights a striking difference between the earlier works and Weise's play, written almost half a century later. ${ }^{1}$ Du Ryer's stage versions (1630 and 1631) have 46 scenes in total, with a cast of thirteen named characters for the 1630 play and twenty-two in 1631. Calderón's Argenis y Poliarco (1637) has three acts and eleven named parts. But Weise's Gedichte von der Sicilianischen Argenis has a cast list naming sixty-five parts for a play that comprises five acts, introductory speeches, prologue and epilogue, with a total of one hundred and five scenes. ${ }^{2}$ The following discussion considers how successful such an apparently unwieldy

1. References to Weise's Argenis are taken from Sämtliche Werke, ed. Lindberg (1971), vol. 1.1.

2. Walther Eggert (1935: 185-186) notes that, in addition to named parts, there were silent walkon roles. The machinery, scenery, effects, and props would also have necessitated a number of boys working backstage. The title page to Weise's Neue Jugend-Lust (1684b) claims that the staging of the 1683 trilogy was a whole-school enterprise. 
text would have been as a stage play, why Weise chose to adapt Barclay's novel, and how he did so.

Christian Weise, son of a teacher, was born in 1642 in the Upper Lusatian city of Zittau. ${ }^{3} \mathrm{He}$ attended his father's grammar school from the age of six, and returned as headmaster in 1678 , remaining until his death thirty years later. ${ }^{4}$ He was first and foremost a pedagogue, engaged in reviewing the school curriculum, teaching boys, and publishing on pedagogical matters. He was also the author of satirical novels, works on rhetoric, history, and politics, and well over fifty plays, which were written for and staged by the pupils at his school, from the youngest, including his son Johann Elias, to the 'Primaner' in their final year. ${ }^{5}$ Weise's contractual duties as headmaster included overseeing the staging of school dramas. ${ }^{6}$ By the 1670 s he was working within an established tradition of three plays per year, performed on stage at the town hall on consecutive days during Shrovetide. ${ }^{7}$ Finding suitable material proved problematic: in the introduction to the volume in which Argenis appeared, Weise notes that many of the plays available to him were written for court performances by professional troupes, and had too few parts for his purposes, compelling him to write his

3. In the late seventeenth century Zittau was part of a federation of six towns in Upper Lusatia (Oberlausitz), which was under the jurisdiction of Electoral Saxony: see Dudeck (1994: 35-38). It bordered Silesia, which, as Habsburg territory, was subject to a re-catholicisation programme in the seventeenth century, including Jesuit control of higher education. As a result, many young Silesians left their territory, which explains the number of Silesian students during Weise's headship. See Hans Arno Horn (1966: 162-168); cited by Marianne Kaiser (1972: 164-165).

4. Weise studied theology at the University of Leipzig, but also attended lectures on philosophy, history and politics. He worked at various courts, and then took up a teaching post at the Augusteum in Weissenfels. The Augusteum was founded in 1664 by August, Duke of Saxony-Weissenfels, a newly-established secundogeniture. Here, according to Kaiser (1972: 122), Weise argued for an increase in the amount of teaching in German.

5. Johann Elias (1678-1709), Weise's only child to survive to adulthood, was almost five years old in 1683, and attended the school between 1681 and 1696: Friedrich (1886: 45). Although he did not act in Argenis, he played the part of Saul's son Esbaal in the biblical drama, and Quisquis, a young charge of the schoolmaster, in Die verkehrte Welt (The Topsy-Turvy World).

6. School statutes of 1596 set down the requirement for plays to be staged: Eggert (1935: 24). In the absence of a headmaster, other teachers could oversee the plays: in February 1662 Weise's father, Elias (1609-1679), was responsible for two plays: see Gärtner (1905: 136).

7. Shrovetide was the end of the school year. On the relation between these plays and the "Gregoriusfest" processions in mid-March to April, which marked the beginning of the following academic year, see Carrdus (2009: 197-214). From 1685, at the request of the boys, Weise moved the play performances from Shrovetide (the end of the school year) to autumn (October / November "Michaeliswoche"): see Wels (2009: 175) and Eggert (1935: 219). Eggert notes that from 1646 the association between the stage at the town hall and the school plays was established. As headmaster, Weise was answerable to the city council, and the good relations that existed between the school and the council were furthered by the plays, which brought both renown and economic benefits to Zittau: Eggert (1935: 32, 274, 276). Wels (2009: 174-175, 177-178) discusses the shift to the simpler stage located in the sixth-form classroom from 1689-1700, with the plays returning briefly to the town hall between 1702 and 1705, and links this to increasing Pietist influence in Zittau. 
own. ${ }^{8}$ The prefaces to his published works also suggest that he made considerable efforts to tailor the part to the actor, in terms of ability, temperament, and speech, ${ }^{9}$ and here we may also add social standing: for example, in 1683 the part of Archombrotus was given to the younger son of Hans Christoph von Schweinitz, chamberlain of Electoral Saxony, and Poliarchus was played by seventeen-year old Christoph Friedrich von Gersdorff, son of the Elector's Privy Councillor. ${ }^{10}$ For Weise the plays were not a distraction from his role as headmaster or from the boys' education, but a vital part of both. ${ }^{11}$ In his introduction to the previous year's plays he describes school as a "shady place", where real life rarely breaks through, but suggests that plays put on at school can help the boys to become "more accustomed to the light". He asks:

How can I allow a future cavalier to depart from my care with his mind full of Latin thoughts, but his tongue unschooled in fitting rhetoric, not to mention with an inability to compose his face and present his body affably? Indeed, since human life itself is like a perpetual comedy, I can do no better than give [the boys] roles to copy that they can try out now as a pastime, but will soon need to assume with all earnestness. ${ }^{12}$

8. Weise (1684b: fols 2)(r-v; repr. Weise, Sämtliche Werke, I, 604-605). Konradin Zeller (1980: 109-17) discusses these practical constraints and the corresponding effect on the length of the plays. He points out that Weise greatly reduced the number of silent, walk-on parts in comparison with other seventeenth-century German dramatists: his intention was to have as many boys speaking publically as possible.

9. See Weise (1690: fols $)\left(6^{v}\right)$ and Weise (1696: fol. a6 $6^{v}$ ); cited in Kaiser (1972: 121).

10. Sebastian Heinrich von Schweinitz, who attended the school between 1681 and 1684, had played the part of Leonisse in Masaniello in 1682: see Friedrich (1886: 39) and Eggert (1935: 198). Christoph Friedrich von Gersdorff (1666-1725) later served as envoy to the Imperial Diet in Regensburg, and was made an Imperial Count in 1725. He was a pupil between 1682 and 1685: see Friedrich (1886: 10).

11. He insists in the preface to two plays published in 1690 that the composition took place in his free time, and that he did not neglect other pressing school duties: Weise (1690: fol. ) (3).

12. "Die Schule ist ein schattichter Ort/ da man dem rechten Lichte gar selten nahe kömt. Indessen darf sich der Schatten mit einigen Vorspielen belustigen/ darbey man des Lichtes nach und nach zu gewohnen pfleget. [...] wie könte ich einen zukünftigen Cavallier von meiner Hand wegziehen lassen/ wann er zwar das Gemüthe mit Lateinischen Gedancken/ hingegen aber die Zunge mit keiner anständigen Beredsamkeit/ viel weniger das Gesichte und den Leib zu keiner Leutseligen Mine DisponirT hätte. Ja weil das Menschliche Leben an sich selbst einer immerwährenden Comödie verglichen wird/ so kan ich nicht besser thun/ als wenn ich die Partheyen bey guter Zeit abzuschreiben gebe/ welche sie anitizo in Kurtzweil versuchen/ bald aber im Ernste vor die Hand nehmen sollen”, in Weise (1683a: fols )?(3 $3^{\mathrm{r}-\mathrm{v}}$; repr. Weise, Sämtliche Werke, I, 600). This emphasis on preparing boys for late-seventeenth century state service explains why the plays were written and performed in German. (The fact that they would also have been comprehensible for the audience of parents and younger siblings must also not be overlooked: that Weise was sensitive to the needs of these audience members is clear from the preface to the Comödien-Probe (1696: fol. b6v); cited by Kaiser (1972:192).) Of the plays cited by Eggert (1935: 6-18), only two appear to have Latin titles: De Wenceslao Juniore (1679) and Axioma Politicum (1683), and these were not performed as part of the three-day annual event in their respective years. 
Weise's pedagogical purpose in staging the plays was twofold: the boys were to gain practical oratorical experience to prepare them to serve the state, and they were to learn political lessons about public life.

Die Sicilianische Argenis was performed on Wednesday 3 March $1683 .{ }^{13}$ On 2 March audience members had been presented with a biblical drama about Saul's persecution of David, ${ }^{14}$ and at the end of Argenis the boy playing the part of Poliarchus invited them to return on the following day for a comedy entitled Die verkehrte Welt (The Topsy-Turvy World). ${ }^{15}$ All three were published in the following year as Neue Jugend-Lust (Youth's New Delight). ${ }^{16}$ The order of the plays mirrored Weise's established division of material for the three-day drama festival: biblical drama, political-historical play and comedy of free invention. ${ }^{17}$ But in 1683 Argenis occupied the historical slot, although

13. Although the sources are not clear, Eggert (1935: 205-206) argues for the likelihood of an afternoon performance.

14. Der verfolgte David is based on I Samuel 18-27: the action takes place after David's defeat of Goliath, during the period of Saul's growing jealously of the young hero. Questions of good government are at the heart of the text, as they are in Argenis, and the prologue presents David and Saul in a series of oppositional statements which make clear David's superiority: Weise (1973: 260).

15. The motif of the world turned upside down was popular in both drama and novels. For example, in 1666 a Jesuit play, Mundus inversus was staged at Hall in the Tyrol, and in 1672 Grimmelshausen published Des Abenteuerlichen Simplicii Verkehrte Welt. Weise discusses the notion in the programme notes from 1683, in which he claims a cycle of images seen in his youth, both amusing and politically instructive, were the impetus for the play. Several broadsheets are contenders: Die Verkehrte Welt hie kan Wohl besehen Jedermann, and Die Narrisch Welt, Strasbourg, Peter Aubry, 1650; and Weise may also have drawn material from other broadsheets, such as [Also stehts in der Welt] and Ala modo monsieurs. Die Newe vmbgekhrte Welt. All four can be seen in Coupe (1966-67: II, plates 126-129. There were also many versions circulating in other European vernaculars. Although Weise's play fills the slot in the annual three-day programme allocated to comedies, the political use to which the motif could be put is seen in John Taylor's Civil War English work Mad Fashions, od [sic] Fashions, All out of Fashions, Or, the Emblems of these Distracted times, London, Thomas Banks [publ.] and John Hammond [printer], 1642; reproduced in The world turn'd upside down: or, A briefe description of the ridiculous fashions of these distracted times, London, John Smith, 1647. The frontispiece to Neue Jugend-Lust (Weise: 1684b) shows, for Die verkehrte Welt, a man standing on his head and wearing his clothes upside down, an image closer to that of the English print than to the upside-down figure in any of the broadsheets cited above, which suggests that Weise's original may have been yet another broadsheet. For a discussion of the "world turned upside down" motif in broadsheets, see Coupe (1966-1967: I, 197-204) and Scholte (1912: 1-8), cited in the discussion of Weise's play by Haxel (1932: 50-54). For more general discussions of the motif see Grant (1973: 103-136) and Donaldson (1970: 21-23). For a modern edition of the play see Weise (1986).

16. Weise $(1684 b)$. The printed play was probably a revised version of the 1683 text, tested on the ground during the 1683 season.

17. Weise comments on this in Lust und Nutz der Spielenden Jugend (1690: fol. ) ( $3^{\mathrm{v}}$; cited in Kaiser 1972:145). Kaiser (1972: 147) suggests that by beginning with the biblical play, the ideal of the "politica Christiana" was to inform the audience's reception of the following plays, although Weise's earlier biblical dramas are not very different from the historical plays in terms of court intrigues and political discussions, and even the comedies present political issues. 
it was based on fictional material, as signalled by the term "Gedichte" (story, invention). ${ }^{18}$ One of the speakers who introduces the play justifies its placement in the programme by explaining that in Barclay's novel Sicily stands for France, ${ }^{19}$ and the programme, circulated in advance to announce the three plays, describes it as a historical fable..$^{20}$

The 1683 programme refers to "the well-known and famous story of Argenis of Sicily" ("das bekandte und berühmte Gedichte [v]on der Sicilianischen Argenis"), suggesting that Barclay's novel was likely to be known by at least some of the audience of parents and civic dignitaries. As well as the Latin text, there were several seventeenth-century German versions, which were largely based on French translations. ${ }^{21}$ The most significant was published in 1626 by the influential poet and theorist Martin Opitz. ${ }^{22}$ It contains twenty-three engravings, re-worked from a French edition. ${ }^{23}$ Despite —or perhaps because of- its popularity, the Latin novel caused some pedagogues concern that their charges were wasting time reading a romance in what they regarded as inferior Latin prose. ${ }^{24}$ This criticism may partially explain several works defending the text on the grounds of the valuable lessons in statecraft that it provided..$^{25}$ One was written by Johann Joachim Möller, who played the part of Meleander in 1683,

18. Melanie Hong (2004: 221) argues that the plays of the second day performed an informatio function in addition to providing opportunities for exercitatio and iudicium, and were used for teaching geography, history and political knowledge.

19. Weise (1971: 382-383). Starting with the Paris Elzevier edition of 1627, interpretative keys to the text began to be appended to the novel.

20. Weise (1683b: fol. ) (2 ${ }^{\text {r }}$ repr. Sämtliche Werke, I, 382-83). Heitner makes this point in his review of the first and third volumes of Weise's Sämtliche Werke, although he fails to note that it was Weise who categorised this as a historical drama by placing it on the second day (1972: 420). 21. For example, Andreas Friderici translated Nicolas Coëffeteau's French version in 1631: see Schmid (1904: 79-80).

22. A second edition was published in Amsterdam in 1644. For a discussion of the text, see Schulz-Behrend (1955) and Schmid (1904: 77-79). It appears that Opitz also had the Latin edition to hand and worked extensively with it.

23. According to Schulz-Behrend (1955: 460), the German engraver copied the original illustrations from the 1623 Paris edition published by Nicolas Buon, with engravings by Leonard Gaultier and Claude Mellan.

24. Schmid (1904: 72-73) cites a 1729 tract by Johann David Schreber, headmaster of the Fürstenschule in Pforta: De Iohannis Barclaii Argenide classicis scholarum libris non addenda [...], as well as Friedrich Christian Baumeister's Exercitationes academicae et scolasticae [...]. Baumeister (1741: 11) describes Argenis as "libellus sic cepit nonnullos, ut omnem in eo legendo aetatem persaepe consumant" (a little book which has so captivated some that they very often waste all their time in reading it).

25. For example, in Joannis Barclai Princeps Praeceptis \& Exemplis, in Argenide Nobiliter Informatus [...] (1674) Johann Schmidt claimed that the novel taught valuable lessons about sovereignty, political circumspection, the role of the court and the prince's advisors, the military, civil war, and the preservation of the monarchy: see Schmid (1904: 170-72). See also the university speech by Nicolaus Knisel: Cleobulus, Seu Boni Consiliarii Exemplar, In Argenide John. Barclaii expressum [...] (1676). 
and delivered as a valedictory speech two months later. ${ }^{26}$ And there is even some evidence that Barclay's novel was used as a school text, albeit in private lessons rather than as part of the school curriculum, for example in Johann Praetorius's grammar school in the Saxon city of Halle. ${ }^{27}$

\section{Weise's Argenis}

Weise's dramas are strikingly different from those of his predecessors of the Second Silesian School (including Andreas Gryphius and Daniel Caspar von Lohenstein). Flouting guidelines laid down by Opitz in the 1620s, Weise mixes comic and serious scenes, even in his tragedies. ${ }^{28}$ Argenis abounds with humorous episodes featuring the court poet Nicopompus and female servants, ${ }^{29}$ or the zealous peasants who arrest Archombrotus, mistaking him for Poliarchus. Weise's peasants mix up their words, ${ }^{30}$ bear comically ironic names, ${ }^{31}$ and demonstrate their inability to adhere to the appropriate register when they drag their prisoner

26. Möller (1683): Dissertationem Philologico-Poëtico-Historico-Politicam: Quid Jo. Barclaii Argenis communi Eruditorum applausu recepta, conducat legentibus? [...]. For a brief discussion, see Schmid (1904: 172-73). As well as discussing Barclay's style, Möller presents his own attempt at decoding the novel, and discusses what Argenis teaches about standing armies, religious unity and other issues. Möller (1659-1733), a Silesian, became an archdeacon in Crossen and author of a number of theological and historical works. For more information see Wedekind (1840: 179).

27. See August Bohse's 1701 translation, Die Durchlauchtigste Argenis: in einer von den vortrefflichsten Staats-Romanen dieser und voriger Zeiten [...], cited in Schmid (1904: 80-81). The title describes Barclay's novel as "one of the most excellent political novels of our times, of all times". In the dedication to his former headmaster Bohse writes of the pleasure and profit he enjoyed in hearing Praetorius analyse Argenis in private lessons (1701: fols $)\left(2^{\mathrm{v}}-3^{\mathrm{r}}\right)$. Praetorius seems to have examined the novel from various angles: stylistic and affective, but also in terms of its moral and political lessons. Bohse (1661-1730) went on to write gallant novels under the pseudonym Talander to teach statecraft to his charges at the Ritterakademie in Liegnitz. (See Willi Flemming, „Bohse, August“, in: Neue Deutsche Biographie, 2 (1955), p. 422 f. [online edition]; URL: <http:// www.deutsche-biographie.de/pnd1 1851296X.html>(accessed 4.7.2014).

28. Kaiser (1972: 118) sees, to some degree, the influence of the English strolling players, who had toured German lands, bringing with them versions of Shakespeare's plays. But the interspersing of comic scenes also allowed Weise a doubling of perspectives, so that an issue such as the correct exercise of power could be explored in two different ways. Zeller (1980: 193) discusses this.

29. The coarse gatekeeper is Mopsa, whose name suggests arrogant sullenness: "mopsig" meant "morose", and in Silesian German "sich mopsig benehmen" was to give oneself airs and graces. (See Jacob and Wilhelm Grimm, Deutsches Wörterbuch, 16 vols in 32 vols (Leipzig: 1854-1901), XII, column 2525 (<http://www.woerterbuchnetz.de/DWB?lemma=mopsig>; last accessed 1.10.16). And Nicopompus flirts with the ice-queen chamber-maid Gelasina, who thaws to his charms in the end. 30. Archombrotus: Ihr Herren/ braucht doch Raison. | Melampus: Ey wir brauchen keine Ranzion. Wir sind keine Soldaten. (Archombrotus: Sirs, I implore you: apply reason. Melampus: We don't need a ransom. We're not soldiers.) Act I, scene 17, in Weise (1971: 454).

31. One is Bucephalus, after Alexander the Great's horse, and another is Melampus, the name of a Greek healer and prophet. Here is an extra level of comedy beyond the slapstick: comedy aimed at the better educated audience members and at the boys. 
into the king's presence. ${ }^{32}$ And Weise uses prose, even for tragedies, where most seventeenth-century playwrights, following classical convention, preferred the elevated register of verse. It is known that Weise dictated his plays to an amanuensis: ${ }^{33}$ the genesis of the text was spoken rather than written text. ${ }^{34}$ But once again this choice was dictated by pedagogical as well as practical reasons: Weise was concerned that his pupils should learn to be natural in their speech; any impression of studied rhetoric was to be avoided in their later careers..$^{35}$ What had been appropriate for large public meetings in Greece and Rome was no longer suitable for contemporary politics, and now that much state business was done in cabinet, it was necessary for the boys to master the art of prudentia sermonis privati (circumspect speech in private circles). ${ }^{36}$ In such contexts, even duplicitous talk was sometimes required, and Weise's plays give plenty of opportunity for the boys to practice this morally problematic, but politically necessary, art. In the introduction to his three plays of 1700 Weise emphasises the importance of "those scenes in which only two people are in conversation and there are constant asides to the audience. For they give us access to the thoughts which do not always match up even to the most intimate speech". ${ }^{37}$ Such devices are undoubtedly useful for transferring a novel with an extradiegetic omniscient narrator onto the stage, where the character's emotions or thoughts need to be made explicit. ${ }^{38}$ But the asides also clearly show the necessity of dissembling in political life, as Weise notes in his Politische Fragen (Political Questions): "Often we have to present a face to the world that is not truly our own, and we cannot allow what we truly are to be seen." ${ }^{39}$ It is important to note that in 1700 Weise describes Barclay

32. Act III, scene 8. In Opitz's translation this takes place in book 1, chapters 14 and 15, and there is no suggestion that they are comic characters. In the play they reappear in the supplication scene (Act II, scene 14), and although they continue to be comic in their presentation, their complaints are fair - for example, that they are taxed more than they earn.

33. See the preface to Lust und Nutz der Spielenden Jugend (1690: fol. ) (3).

34. Weise (1690: fol. $)\left(7^{v}\right)$ suggests that his plays work better on the stage than the page because jokes that often depend on the dialect of the actor may not come across in the printed text.

35. "In Summa, man soll die Auffrichtigkeit und die Wahrheit, oder doch die kluge Vorsichtigkeit mehr gelten lassen als die studirte Beredsamkeit" (In summary, what really counts is honesty and truth, or at least prudent caution, rather than studied rhetoric), in Weise (1700: fol. $4^{\mathrm{r}}$ ); cited in Kaiser (1972: 161).

36. Weise (1700: fols 3rff); cited in Kaiser (1972: 159). This is also discussed by Zeller (1981: 545). 37. "Vornehmlich haben dieselbigen Szenen was zu bedeuten/ da zwei Personen nur miteinander reden/ und allzeit etwas ad Spectatores à part geredet wird. Denn hierdurch werden die Gedancken verstanden/ welche bey der vertraulichsten Rede mit dem Munde nicht allezeit übereinstimmen": Weise (1700: fol. a6v); cited in Kaiser (1972: 160). Eggert (1935: 230) notes that "heimlich sprechen" (speaking in secret) is often a feature of Weise's plays.

38. A good example is Act I, scene 12, where Archombrotus's asides make clear to the audience that he sees what Poliarchus cannot admit: his love for Argenis. The narrator's functions are also partially fulfilled by the stage directions.

39. "Wir müssen uns offt anders von außen stellen/ als wir sind; und was wir sind/ das dürffen wir nicht mercken lassen" (Weise 1690, rev. 1693: 439); cited in Kaiser (1972: 126). 
as a "master of political secrets", and cites several passages from Argenis to demonstrate the author's mastery of the art of circumspect private speech. ${ }^{40}$

Weise discusses the problems of adapting historical material for the stage in a number of play prefaces: the action must be coherent and the characters' motivations emotionally plausible, often necessitating an embellishment of the historical material. ${ }^{41}$ Argenis posed a rather different problem. Here was a text well-known to some - perhaps many - of his audience, which was itself a free invention, fiction rather than historical fact. In the preface Weise offers some interesting observations about its adaptation for the stage. First, he apologises for the fact that he could not contain it within the conventional five acts: the material was simply too long and involved, so he was obliged to add a prologue sketching the background and an epilogue in which the intrigues are brought to a happy resolution..$^{42} \mathrm{He}$ also redistributes scenes, although he is adamant that the essential action of the novel is retained, ${ }^{43}$ and he even attempts to reproduce some of the gorier episodes, such as the moment Lycogenes' severed head is brought onto the stage. ${ }^{44}$ The prologue provides the back-story: Lycogenes' revolt, and Poliarchus's deliverance of Meleander and Argenis whilst disguised as Theocrine, which in the novel is related by Selenisse to Radirobanes; ${ }^{45}$ and Archombrotus's arrival in Sicily, his encounter with Timoclea and the bandit attack on Poliarchus, with which the novel opens, come only halfway through Act I. Many of the long discussions of the novel are necessarily curtailed or pithily summarized. In Act I, scene 12 Poliarchus explains Sicily's situation to the newcomer, Archombrotus:

Poliarchus: The King is very gracious, and judges others according to his own character.

ARchombrotus: In that way his mercy is abused. ${ }^{46}$

40. Weise (1700: fols $\left.\mathrm{a} 4^{\mathrm{v}}-\mathrm{a} 6^{\mathrm{r}}\right)$.

41. Weise, "Zwischenbemerkung im Zittauischen Theatrum", in Weise (1971: 602).

42. "[D]a thut man wohl unrecht/ wenn man nicht den Schuch nach dem Fusse/ sondern den Fuß nach dem Schuche zwingen will/ das ist/ wenn man nur auf die Form geht/ daß 5. Actus erhalten werden/ obgleich die Materie und die Sache selbst verstümmelt und der besten Galanterie beraubet wird": Weise (1971: 377). (It would be wrong to force the foot to fit the shoe, rather than the other way around, and this would happen if one were to mutilate the material and the content in order to fit it into five acts, robbing it of its best gallantry, purely for form's sake.)

43. Weise (1971: 378).

44. Act III, scene 21; in Barclay, Argenis, book 3, chapter 2. This scene is cited by Eggert (1935: 136-137). It pales by comparison with Act V, scene I of Der verfolgte David, where the sleeping Saul is visited by the murdered priests of Nob and their families, including a disembowelled baby.

45. Samuel Grosser (1664-1736), who played Selenisse, was a Silesian who attended the school between 1683 and 1684: see Friedrich (1886: 23). He later taught in Altenburg and Leipzig, and became headmaster of the grammar school in the Lusatian city of Görlitz in 1695. He also staged plays, including a reworking of Die verkehrte Welt — Die neugierige Alamode-Welt (1724): see Gajek (1994: 325). Grosser acknowledged his pedagogical debt to Weise in his 1710 Vita Christiani Weisi [...].

46. "Poliarchus: Der König ist sehr güthig/ und urtheilet von andern aus seinem Gemüthe. | Авсномвrotus: Damit wird die Gnade mißbraucht”: Weise (1971: 442). 
Not only does this reduce to its essence Poliarchus's long explanations in book 1, chapter 2; it also shows that Archombrotus will be a wiser and more political king than his (as yet unknown) father.

Weise identifies two noteworthy alterations in his drama. The figure of Nicopompus, considered by some critics to stand in the novel for Barclay himself, is one. ${ }^{47}$ As theatre audiences had come to expect a fool character, a pickleherring, wise Nicopompus has to undergo a personality change. ${ }^{48}$ This is seen clearly in the crassly absurd and inappropriate song he composes when he learns of Poliarchus's supposed drowning, which contrasts strikingly with Argenis's grief. ${ }^{49}$ Weise would later describe the comic element in his plays as sugar sprinkled on the less digestible food, and would claim that the pickleherring often provides the best commentary on the action..$^{50}$ The second alteration reflects Weise's concerns for the moral well-being of his charges. In book I, chapter 20 of the novel Poliarchus comes to Argenis in disguise when she is offering a sacrifice to Pallas Athena. Pre-empting potential criticism of his theatre, not least by Pietists, Weise edits out references to pagan religion, so that Argenis instead receives petitions from the people on her father's behalf, and is secretly visited in this way by her disguised lover. ${ }^{51}$

In a detailed examination of Weise's staging of his plays, Walther Eggert concludes that a performance of Argenis would have taken around five and a half hours without interval. ${ }^{52}$ How was the audience's attention held for so long, especially as the parents of some boys would see their sons grace the stage only briefly? First, the play is a "Singspiel", with music and dancing breaking up the

47. On Nicopompus as Barclay's mouthpiece, see Siegl-Mocavini (1999: 36, 306).

48. Weise (1971: 377).

49. Act II, scene 3. The part was played by one of Weise's favourite pupils, Gottfried Hoffmann (1658-1712), who spent four years at the school between 1681 and 1685, where he acted as Weise's amanuensis, and therefore played a crucial role in shaping the plays of these years. On Weise's death he returned to Zittau, serving as headmaster until his death in 1712. Hoffmann had also played the important pickleherring role (Allegro) in Masaniello: see Wenzel (1721: 22-32), Friedrich (1886: 16) and Wels (2009: 181-185).

50. Weise (1700: fols a $\left.6^{\mathrm{v}}-\mathrm{a} 7^{\mathrm{r}}\right)$. On the role of the pickleherring and Weise's theories on the alternation of comic and serious scenes see Zeller, Pädagogik und Drama (1980: 180-197, 229-238). 51. He discusses his objections to Barclay's inclusion of a pagan ceremony in both the programme notes (1683b: fol. ) $\left(2^{\mathrm{r}-\mathrm{v}}\right)$ and in the preface to Neue Jugend-Lust in the following year (1971: 606). It is also striking that the David and Saul play ends before the appearance of the Witch of Endor (I Samuel 28). Although it would have been dramatically more satisfactory to have concluded the play with Saul's death, to do so would have required Weise to stage this problematic episode. (The ghost scene at the beginning of Act $\mathrm{V}$ is less problematic because it can be interpreted as a guilty conscience manifesting itself in dreams, in time-honoured dramatic convention: see footnote 44).

52. Eggert analyses evidence gleaned from contemporary city chronicles, letters, Weise's directorial notes, and the stage directions themselves. Only a few of the directorial notebooks survive because in 1757 parts of Zittau were badly destroyed by the Austrian bombardment of the city during the Seven Years War: see Eggert (1935: 88, 270). 
action. The music is by the organist and musical director of St John's church in Zittau, Johann Krieger (1652-1735), younger brother of the better-known Johann Philipp, who had known Weise in Weissenfels..$^{53}$ The part of Gelasina was filled by eighteen-year-old Johann Christoph Schmidt, who had been a singer at the court chapel in Dresden, and was therefore able to take on this role, which required the ability to sing solos and duets. ${ }^{54}$ And the dancing in the plays served not only to offer variety to the audience, but also gave the boys an opportunity to demonstrate mastery of an important social skill. ${ }^{55}$

The performance took place on a divided stage with several pairs of painted flats. ${ }^{56}$ The inner stage appears to have been separated from the rest by a curtain, which opened at significant moments. For the most part in Argenis it denotes the inner sanctum of Meleander and Argenis, into which certain events intrude. Meleander first appears in this theatrical space: he is in bed in the sanctuary of his daughter's secluded court, and this introduction to the monarch doubly exposes his weak and womanish character, which has endangered the realm. ${ }^{57}$ The inner stage is also used for the revelations from Hianisbe's letter in the epilogue: family relationships and the security of the realm are here intimately connected and simultaneously resolved. Finally, the inner stage can be used to conceal as well as reveal. In Act II it conceals the moment at which Argenis hears of Poliarchus's supposed death: the audience only sees the result as she stumbles through the curtain wrestling with Selenisse, who is intent on preventing her suicide. ${ }^{58}$

If Weise's primary purpose in staging his plays was pedagogical, what were the lessons that the boys could be expected to learn from Argenis? The material

53. See Scheitler (2009: 406). Krieger collaborated with Weise on a number of plays, music for which can be found in his Neue Musicalische Ergetzligkeit (New Musical Delight) of 1684, which includes several arias from Argenis. The songs from Argenis include that sung by Cypassis in the sixth scene of the prologue, "Ihr Leute seht die Tugend reisen" from Act I, scene 6, and "Seyd Lustig" from the sixth scene of the epilogue: Krieger (1684: 24-29, 29-30 and 31-36 respectively).

54. Schmidt (1664-1728) became a composer, organist and musical director. For more information, see Sauer: "Schmidt, Johann Christoph", and Eitner (1890: 736-737). According to Sauer he was a pupil at the Zittau grammar school between 1681 and 1683, but according to Friedrich's transcription of the school records (1886: 36 - under 'Schmied') he matriculated in 1682 .

55. Eggert (1935: 265).

56. Eggert deduces this from a number of stage directions, concluding that the stage was like that used in Italian opera of the period (1935: 68-76.)

57. Meleander's enemies describe him as "weibisch" (womanish) in Act II, scene 15: Weise (1971: 492).

58. The front curtain demarcates the action of the play from the moments in which the boys speak as themselves: at the end of the epilogue, the actor playing Poliarchus steps in front of the curtain to thank members of the audience for their attention and to invite them to return on the following day for the final play in the trilogy. 
shows similarities with many of his other historical dramas. Elida Maria Szarota notes a pattern for historical plays with two factions: the king's loyal faction on the one hand, and the self-seeking conspirators on the other. ${ }^{59}$ And the focus of Argenis is certainly political, a term Weise defined as concerning the theory of how a state should be ruled wisely. ${ }^{60}$ Meleander is an example $e x$ negativo: his lack of popularity allows Lycogenes to gain ground (I.3), he is described on several occasions as womanish, ${ }^{61}$ he is gullible, and he makes unwise decisions, disregarding advice from his counsellors. ${ }^{62}$ Radirobanes is also a poor example for the boys, endangering his kingdom of Sardinia in pursuit of Argenis, whereas the two heroes are the young monarchs-in-waiting, Poliarchus and Archombrotus, who learn valuable lessons about statesmanship over the course of the action, lessons that will equip them, like the school-boys, for their future roles. The play also illustrates the danger that a country exposed to civil war can easily fall prey to the ambitions of a third party, as Sicily so nearly does to Sardinia, a lesson neatly summarised by Archombrotus through the analogy of a third dog who carries away the bone over which two others are fighting. ${ }^{63}$ Yet despite the rather negative portrayal of the monarch in the person of Meleander, Weise, like Barclay, is clear that a people may not rise up against its king, and in his political writings he rejects monarchomachism. ${ }^{64}$ The play also deals with political questions at the level at which the boys would be operating as minor noblemen or holders of civic office, addressing, for example, the need for a state to be financially well-run, or the importance of controlling the military. ${ }^{65} \mathrm{Mar}-$ ianne Kaiser states that Weise's aim was for the boys to acquire prudentia rather than sapientia, circumspection over and above academic wisdom. ${ }^{66} \mathrm{~A}$ political

59. Szarota (1976: 175) identifies this pattern in Der gestürtzte Marggraff von Ancre (1681), Der Fall des Frantzösischen Marschalls von Biron (1693), Der Spanische Favoriten=Fall An dem Grafen von Olivarez (1685), and D[er] geplagt[e] und wiederum erlöst[e] Regnerus in Schweden (1684).

60. "Die Politica ist eine Lehre/ wie man einen Staat klug regieren soll" (1690; rev. 1693: 1); cited by Kaiser (1972: 129).

61. II. 15: Oloodemus: "Wehe dem Lande/ dessen König zum Weibe wird" (Alas for the land whose king becomes a woman): Weise (1971: 492).

62. In the prologue he is advised against hiding Argenis away from the people (scene 12).

63. Act I, scene 12: Weise (1971: 443).

64. We see this in Politische Fragen: "möglichst daß ein Ober-Herr seine Gewalt mißbrauchet ... noch tausendmahl möglicher, daß ein Thier mit so viel Köpffen allezeit etwas ungereimtes gegen die Obrigkeit würde einzuwenden haben": Weise (1690; rev. 1693; 132); cited by Kaiser (1972: 132). (It is possible that an overlord may abuse his power; but it is a thousand times more likely that a beast with so many heads may, at any point, make some absurd charge against the authorities.) The prophet Samuel clearly supports the notion of divine-right monarchy in Der verfolgte David (Act II, scene 2). Kaiser (1972: 128-33) suggests that Weise was nonetheless wary of absolutism. For a discussion of Barclay's views on monarchomachism see Siegl-Mocavini (1999). 65. The rebels Eristhenes and Menocritus identify these as two possible channels through which Meleander's rule might be undermined (Act I, scene 2): Weise (1971: 420).

66. Kaiser (1972: 125). Zeller (1981: 547) describes prudentia as "das Kernstück [Christian Weises] Bildungsprogramms" (the core of Weise's educational programme); and Fritz Martini (1972; repr. 
man, writes Weise, should concern himself with what is possible rather than what is ideal, ${ }^{67}$ even when this entails behaving in a way that one would not choose, all things being equal. We see this in Timoclea's Machiavellian response to Poliarchus's high-minded reluctance to take refuge in the underground passages: "In an emergency", she tells him, "deception becomes a matter of prudence", ${ }^{68}$ and we are reminded of Weise's comment that it is often necessary in public life to dissemble: to disguise one's true feelings and present a mask to the world. ${ }^{69}$ Although it is set in the court of an absolute monarch of pre-Roman times, the action of Weise's Argenis is to reflect recognisable political behaviour and dilemmas to the boys and audience alike, ${ }^{70}$ and the tripartite frontispiece to Neue Jugend-Lust shows for Argenis two winged figures holding up a mirror to an armed man, with the motto "Speculum docet" (the mirror instructs). ${ }^{71}$

Few of Weise's plays are well-known today: his tragedy Masaniello about the Neapolitan fishermen's revolt of 1647, and his comedy, Bäurischer Machiavellus (The Peasant Machiavellus), are exceptions, and even they are known primarily as texts to be studied rather than a regular part of German repertoire: page plays rather than stage plays. And although Weise envisaged that his plays would be performed by other school theatres, ${ }^{72}$ there is only evidence of two near-contemporary performances of Argenis: one at the school in the Upper Lusatian city of Bautzen (Budissen) in Shrovetide 1693, where it was performed together with Weise's Abraham and Isaac drama in February $1693,{ }^{73}$ and one in Görlitz in 1695, at the grammar school under the headmastership of Christian Funcke, who had already staged a number of Weise's

1992: 189) writes of "ein[e] neu[e] bürgerlich-praktisch[e] Weltlichkeit [...], der es nicht mehr um die vertikale Existenz des Menschen zwischen Himmel und Hölle, sondern um die horizontale Existenz des Menschen in dieser realen irdischen Welt ging" (a new middle-class, practical worldliness [...], which was no longer concerned with human existence on the vertical axis between heaven and hell, but with the horizontal axis of human existence in this real earthly world).

67. Weise (1690; rev. edn. 1693: 534); cited in Kaiser (1972: 132).

68. "Der Betrug wird im Falle der Noth zur Klugheit", Act I, scene 14, Weise (1971: 448).

69. Szarota $(1976: 201,202)$ claims that Poliarchus represents Weise's ideal of a politicus, who can control his passions and maintain an outward equilibrium. But this ability is acquired over the course of the action; the young man learning to be a politicus serves as a direct model for Weise's pupils, who are learning the same lesson.

70. One of the introductory speakers draws a clear link between the boys acting on the school stage, and notable audience members playing their parts "auf der Schau-Bühne einer friedsamen und gesegneten Republique" (on the stage of a peaceful and blessed republic): Weise (1971: 383). 71. In the 1708 preface to his earlier comedy Ungleich und gleich gepaarte Liebes=Alliance, Weise describes drama as "vitae humanae speculum" (a mirror of human existence); cited in Kaiser (1972: 163), and the stage as a (critical) mirror is the subject matter of the frontispiece and verse explanation of Weise's 1693 Freymüthiger und höflicher Redner; cited by Eggert (1935: 355).

72. Weise (1971: 604-605).

73. The programme was published in Bautzen by Andreas Richter. Irmtraut Scheitler (2013: 337) identifies the director as Martin Grünwald (1664-1716), one of Weise's pupils in Zittau between 1672 and 1687: see Friedrich (1886: 11). 
dramas. ${ }^{74}$ In comparison with some of Weise's other school dramas, Argenis is a weak play: it is cumbersome, and the constraints of the long cast list, common, of course, to much seventeenth-century school drama, make the action stilted, and somewhat rushed. ${ }^{75}$ Nonetheless, an examination of the play yields a fascinating glimpse into the practice of school drama at the end of the seventeenth century, and into Weise's pedagogical and political theories.

74. Eggert (1935: 334); Gajek (1994: 324).

75. In Lust und Nutz der Spielenden Jugend (1690: fol. ) (6r) Weise hints that the need to produce so many parts may, in some cases, have hobbled the dramatic effect. He also concedes that the length of the plays requires a certain speed of action to keep the audience's attention (fol. $)\left(7^{\mathrm{r}}\right)$. He makes similar points in the preface to the Comödien-Probe (1696: fols a2 ${ }^{\mathrm{r}}-\mathrm{a} 6^{\mathrm{v}}$ ). 


\section{Bibliography}

BAumeIsTER, Friedrich Christian, Exercitationes academicae et scolasticae: varii generis argumenta ad recentiorem philosophiam elegantiorisque stili cultum spectantia complexae, Leipzig and Görlitz, Siegmund Ehrenfried Richter, 1741.

Bohse, August, Die Durchlauchtigste Argenis: in einer von den vortrefflichsten Staats=Romanen dieser und voriger Zeiten [...], Leipzig, Johann Ludwig Gleditsch, 1701.

Calderón de la Barca, Pedro, Argenis y Poliarco, in Obras completas, vol. 2: Comedias, ed. Angel Valbuena Briones, Madrid, Aguilar, 1956, pp. 1916-1952.

Carrdus, Anna, "Christian Weise und das Gregoriusfest in Zittau", Poet und Praeceptor. Christian Weise (1642-1708) zum 300. Todestag, ed. Peter Hesse, Dresden, Neisse Verlag, 2009, pp. 197-214.

Coërfeteau, Nicolas, Historie Von Poliarchus und Argenis/ Fast nach Herrn Barclayen Lateinischen Von F. N. Coeffeteau [...] kürtzlich beschrieben [...], trans. from the French by Andreas Friderici, Leipzig, Elias Rehefeld, 1631.

Coupe, William A., The German Illustrated Broadsheet in the Seventeenth Century: Historical and Iconographical Studies, Bibliotheca bibliographica Aureliana, 17, 2 vols, Baden-Baden, Heitz, 1966-1967.

Donaldson, Ian, The World Upside-down: Comedy from Jonson to Fielding, Oxford, Clarendon, 1970.

Dudeck, Volker, "Das Zittau Christian Weises", Christian Weise - Dichter, Gelehrter, Pädagoge: Beiträge zum ersten Christian-Weise-Symposium aus Anlass des 350. Geburtstages, Zittau 1992, ed. Peter Behnke and Hans-Gert Roloff, Jahrbuch für internationale Germanistik, 37, Bern, Lang, 1994, pp. 27-51.

Du Ryer, Pierre, Argenis et Poliarque ou Theócrine. Tragicomédie, Paris, Nicolas Bessin, 1630.

—, L’Argenis du Sr. Du Ryer: tragi-comédie: dernière iournée, Paris, Nicolas Bessin's widow, 1631.

Eggert, Walther, Christian Weise und seine Bühne, Germanisch und Deutsch: Studien zur Sprache und Kultur, 9, Berlin, de Gruyter, 1935.

EItner, Robert, "Schmidt, Johann Christoph", Allgemeine Deutsche Biographie, 31 (1890), 736-737; online edition: Last accessed 4.10.14, $<$ http://www.deutsche-biographie.de/pnd128511222.html?anchor=adb>.

Friedrich, Oskar, Album des Gymnasiums zu Zittau. Zur Erinnerung an die dreihundertjährige Jubelfeier der Begründung des Gymnasiums, Zittau, Menzel, 1886.

GajeK, Konrad, "Zur Rezeption Christian Weises auf dem barocken Schultheater in Schlesien und der Lausitz", Christian Weise - Dichter, Gelehrter, Pädagoge: Beiträge zum ersten Christian-Weise-Symposium aus Anlass des 350. Geburtstages, Zittau 1992, ed. Peter Behnke and Hans-Gert Roloff, Jahrbuch für internationale Germanistik, 37, Bern, Lang, 1994, pp. 315-330. 
GärTner, Theodor, Quellenbuch zur Geschichte des Gymnasiums in Zittau. I: Bis zum Tode des Rektors Christian Weise (1708), Veröffentlichungen zur Geschichte des gelehrten Schulwesens im Albertinischen Sachsen, II: Urkundenbücher der Sächsischen Gymnasien, I, Leipzig, Teubner, 1905.

Grant, Helen F., "The World Upside Down", in Studies in Spanish Literature of the Golden Age: presented to Edward M. Wilson, ed. R. O. Jones, Colección Tamesis, series A.30, London, Tamesis Books, 1973, pp. 103-136.

Grosser, Samuel, Vita Christiani Weisi, gymnasii Zittaviensis rectoris [...], Leipzig, Johann Ludwig Gleditsch and Moritz Georg Weidmann, 1710.

Haxel, Heinrich, Studien zu den Lustspielen Christian Weises (1642-1708): ein Beitrag zur Geschichte des deutschen Schuldramas, Stettin, Ostsee-Verlag, 1932.

Heitner, Robert R., review of Christian Weise, Sämtliche Werke, I and III, ed. John D. Lindberg, The Journal of English and Germanic Philology, 71 (1972), pp. 418-420.

Hong, Melanie, 'Europäische Orientierung in Christian Weises historischen Dramen', Kulturelle Orientierung um 1700: Traditionen, Programme, konzeptionelle Vielfalt, ed. Sylvia Heudecker, Dirk Niefanger and Jörg Wesche, Frühne Neuzeit, 93, Tubingen, Niemeyer, 2004.

Horn, Hans Arno, Christian Weise als Erneuerer des deutschen Gymnasiums im Zeitalter des Barock. Der "Politicus" als Bildungsideal, Weinheim/Bergstr.: Beltz, 1966.

KAISER, Marianne, Mitternacht - Zeidler - Weise. Das protestantische Schultheater nach 1648 im Kampf gegen höfische Kultur und absolutistisches Regiment, Göttingen, Vandenhoeck \& Ruprecht, 1972.

Kämmel, Heinrich, "Grosser, Samuel”, Allgemeine Deutsche Biographie, 9 (1879), 749-50; online edition: 13-04-14, <http://www.deutsche-biographie. de/pnd10014683X.html?anchor=adb>.

Knisel, Nicolaus Cleobulus, seu boni consiliarii exemplar, in Argenide Joh. Barclaij expressum [...], Stuttgart, Johann Weyrich Rösslin, 1676.

KrIEger, Johann, [...] Neue Musicalische Ergetzligkeit/ Das ist Unterschiedene Erfindungen Welche Herr Christian Weisel in Zittau Von Geistlichen Andachten Politischen Tugend=Liedern Und Theatralischen Sachen bishero gesetzet hat; Jn die Music gebracht und der Tugend=liebenden Jugend vornehmlich recommendiret, Frankfurt and Leipzig, Christian Weidmann [publisher] and Johann Köler [printer], 1684; repr. Dokumentation zur Geschichte des deutschen Liedes, 7, Hildesheim, Olms, 1999.

Martini, Fritz, afterword to Christian Weise, Masaniello, ed. Fritz Martini, Stuttgart, Reclam, 1972; repr. 1992, 187-220.

Möller, Johann Joachim, Dissertationem Philologico-Poëtico-Historico-Politicam: Quid Jo. Barclaji Argenis communi Eruditorum applausu recepta, conducat legentibus? [...], Zittau, Michael Hartmann, 1683.

OpITz, Martin, Johann Barclajens Argenis Deutsch gemacht durch Martin Opitzen [...], Breslau, David Müller, 1626; repr. Die Übersetzung von John Baclays 
Argenis, Gesammelte Werke: kritische Ausgabe, vol. 3, ed. George SchulzBehrend, Stuttgart, Hiersemann, 1970, 2 parts.

SaUER, Dorothea, "Schmidt, Johann Christoph", Sächsische Biografie, Institut für Sächsische Geschichte und Volkskunde, ed. Martina Schattkowsky. Last accessed: 3.10.16, <http://saebi.isgv.de/biografie/Johann_Christoph_ Schmidt_(1664-1728)>.

Scheitler, Irmgard, "Schauspielmusik in der Frühen Neuzeit. Weises Der Gedemühtigte und wiederum erhöhte Nebuchandnezar in Assyrien", Poet und Praeceptor. Christian Weise (1642-1708) zum 300. Todestag, ed. Peter Hesse, Dresden, Neisse Verlag, 2009, pp. 405-21.

—, review of Ulrike Wels, Gottfried Hoffmann (1658-1712). Eine Studie zum protestantischen Schultheater im Zeitalter des Pietismus, Epistemata Literaturwissenschaft, 744 (Würzburg: Königshausen \& Neuburg, 2012), in Pietismus und Neuzeit, 39 (2013), pp. 335-344.

Schmid, Karl Friedrich, John Barclays Argenis. Eine literarhistorische Untersuchung. I. Ausgaben der Argenis, ihrer Fortsetzungen und Übersetzungen, Literarhistorische Forschungen, 31, Berlin and Leipzig, Felber, 1904.

Schmidt, Johann, Joannis Barclai Princeps praeceptis \& exemplis, in Argenide nobiliter informatus. Sive aphorismi politici, ipsis Barclaj verbis nervosè concepti, \& exemplis ipsi nativis explicati [...], Oldenburg, Johann Erich Zimmer, 1674.

Scholte, Jan Hendrik, "Johann Jacob Christoph von Grimmelshausen und die Illustrationen seiner Werke", Zeitschrift für Bücherfreunde, 4 (1912), pp. 1-21.

Schreber, Johann David, De Iohannis Barclaii Argenide [...], Naumburg, Balthasar Bossögel, 1729.

Schulz-Behrend, George, "Opitz Übersetzung von Barclays Argenis', PMLA, 70 (1955), 455-73.

Siegl-Mocavini, Susanne, John Barclays "Argenis" und ihr staatstheoretischer Kontext: Untersuchungen zum politischen Denken der Frühen Neuzeit, Tübingen, Niemeyer, 1999.

Szarota, Elida Maria, Geschichte, Politik und Gesellschaft im Drama des 17. Jahrhunderts, Bern and Munich, Francke, 1976.

Wedekind, Eduard Ludwig Geschichte der Stadt und des Herzogthums Crossen, Crossen, Riep, 1840.

Weise, Christian, [...] Zittauisches Theatrum [...] 1. Von Jacobs doppelter Heyrath. 2. Von dem Neapolitanischen Rebellen Masaniello. 3. Jn einer Parodie eines neuen Peter Sqvenzens von lautern Absurdis Comicis, Zittau: Johann Christoph Mieth [publisher] and Michael Hartmann [printer], 1683a.

—, [...D] as Zittauische Theatrum Sol nach bißheriger Gewonheit wiederum eröffnet werden/ Und haben die geneigten Liebhaber zu erwarten Dienstags den 2. Mart. Davids unschuldige Verfolgung. Mitwochs den 3. Mart. Das bekandte und berühmte Gedichte Von der Sicilianischen Argenis Donnerstags den 4. Mart. ein neues Lust=Spiel Von der Verkehrten Welt. gestallt solches gebühren- 
der maßen hiermit öffentlich recommendiret wird/ durch C. W. R., [Zittau], Michael Hartmann, $1683 b$.

-, Jo. Barclaji Gedichte Von der Sicilianischen Argenis, Wie selbiges Den 3. Mart. 1683. Auf das Zittauische Theatrum geführet worden, Leipzig, Christian Weidmann [publisher] and Johann Köler [printer], $1684 a$.

—, [...] Neue Jugend=Lust/ Das ist/ Drey Schauspiele: I. Vom verfolgten David, II. Von der Sicil, Argenis, III. Von der verkehrten Welt. Wie selbige Anno MDCLXXXIII. Von den gesamten Studirenden im Zittauischen Gymnasio aufgeführet worden, Frankfurt and Leipzig, Christian Weidmann [publisher] and Johann Köler [printer], $1684 b$.

-, [...] Lust und Nutz der Spielenden Jugend bestehend in zwey Schau= und Lust=Spielen vom Keuschen Joseph und der Unvergnügten Seele [...], Dresden and Leipzig, Johann Christoph Mieth [publisher] and Christian Banckmann [printer], 1690.

—, [...] Politische Fragen/ Das ist: Gründliche Nachricht Von der Politica, Welcher Gestalt Vornehme und wohlgezogene Jugend hierinne einen Grund legen/So dann aus den heutigen Republiqven gute Exempel erkennen/Endlich auch in practicablen Staats=Regeln den Anfang treffen soll [...], Dresden, Johann Christoph Mieth and Johann Christoph Zimmermann, 1690; rev. ed. 1693a.

-, [...] Freymüthiger und höfflicher Rednerl das ist/ ausführliche Gedancken von der Pronunciation und Action, was ein getreuer Informator darbey rathen und helffen kan/ Bey Gelegenheit Gewisser Schau=Spiele [... entworffen, [Leipzig], Johann Friedrich Gleditsch, 16936.

—, [...] Comödien Probe/ Von Wenig Personen/ Jn einer ernsthafften Action Vom Esau und Jacob/ Hernach in einem Lust=Spiele Vom Verfolgten Lateiner: Nebst einer Vorrede De interpretatione dramatica, Leipzig, Jakob Gerdesius, 1696.

-, Neue Proben von der vertrauten Redens=Kunstl Das ist: drey Theatralische Stückel I. Von dem Spanischen Favoriten Olivarez. II. Von dem jungen Könige Wentzel in Böhmen. III. Von dem träumenden Bauer am Hofe Philippi Boni in Burgundien. Welche vormahls auff dem Zittauischen Schau=Platz gesehen worden. Nu aber nützlich und vergnügt zu lesen seyn/ nebst einer Vorrede heraus gegeben [...], Dresden and Leipzig, Johann Christoph Mieth and Johann Christoph Zimmermann, 1700.

—, Christian Weisens ungleich und gleich gepaarte Liebes=Alliance [...], Görlitz, Jacob Rohrlach, 1708.

—, Sämtliche Werke, I, Historische Dramen, I, ed. John D. Lindberg, Berlin, de Gruyter, 1971.

—, Sämtliche Werke, V, Biblische Dramen, II, ed. John D. Lindberg, Berlin, de Gruyter, 1973.

—, Sämtliche Werke, XII.1, Lustspiele, III, ed. John D. Lindberg, Berlin, de Gruyter, 1986.

Wels, Ulrike, "Die Theaterpraxis am Zittauer Gymnasium im Zeitalter des Pietismus unter Christian Weise (1678-1708) und Gottfried Hoffmann 
(1708-1712)", Poet und Praeceptor. Christian Weise (1642-1708) zum 300. Todestag, ed. Peter Hesse, Dresden, Neisse Verlag, 2009, pp. 167-187.

Zeller, Konradin, Pädagogik und Drama: Untersuchungen zur Schulcomödie Christian Weises, Studien zur deutschen Literatur, 61, Tübingen, Niemeyer, 1980.

—, "Der Hof im Drama Christian Weises. Zu Form und Funktion der Favoritendramen", Europäische Hofkultur im 16. Und 17. Jahrhundert, ed. August Buck, Georg Kaufmann, Blake Lee Spahr, and Conrad Wiedemann, Wolfenbütteler Arbeiten zur Barockfoschung, 10, Hamburg, Hauswedell, 1981, vol. III, pp. 543-549. 
